\title{
Clause Structure of Javanese Language
}

\author{
The Study of Lexical Functional Grammar
}

\author{
Murdiyanto \\ Universitas Negeri Surabaya \\ Surabaya, Indonesia \\ murdiyanto@unesa.ac.id
}

\author{
Ratna Ayu Pawestri K.D \\ Universitas Negeri Surabaya \\ Surabaya, Indonesia \\ ratna.pusbah@gmail.com
}

\begin{abstract}
The research aims to examine the clause structure phenomena in Javanese language, namely basic clause structure of Javanese language. This research uses lexical functional grammar theory as its underlying theory to solve the problems within the sentence structure in Javanese language. A qualitative approach is taken as the research methodology in this research. The research data consists of words, phrases, clauses, and sentences which is gathered from "Ting" by Dyah Kushar, and "Watesing Kesabaran" by Tiwiek, SA. The conclusion reveals that the basic clause structure of Javanese language could be classified into some types of a predicative clause such as base, derivative, non-verbal (predicate, adjective, predicate noun), and verbal.
\end{abstract}

Keywords - basic clause structure; Javanese language

\section{INTRODUCTION}

Language lies in human's minds who speak the language, and the existence of language is humans' ability to learn at least one language and to use it in general [1]. Language observers and experts conducted various methods and theories to develop several linguistics branches such as phonology, morphology, syntax, and semantics. They also combined those linguistics branches with other disciplines to investigate the Javanese language phenomenon. Referring to those four linguistics branches, this research focuses on syntax. The language which will be investigated is Javanese language in which focuses on the grammatical sentence of Javanese language. This research applies lexical functional grammar (LFG) theory.

Lexical Functional Grammar is classified into nontransformational generative grammar-based on lexicon [2], [3], [4]. As part of the generative theory, LFG refers to the basic concept of generative grammar consisted of modules, principles and constraints forming a mechanism which is able to produce language expressions in unlimited number [5].

Based on the lexical entries theory, an element can produce other elements to build another construction depending on its lexical element [6]-[8]. It means that lexical items play an important role as a determining factor to establish linguistic construction, including the construction of sentences. Both lexical term and functional term are explained to distinguish this theory with other theories. In LFG theory, "functional" term stands for "mathematical function" which is related to the conception of grammatical relation, such as subject, object, or etc. It can be modeled in a matrix structure with grammatical relation and other information. Therefore, it forms double attributes and has value in a formal structure which is called as functional structure (str-f). As a result, subject, object, and OBL are grammatical functions in LFG theory.

\section{KINDS OF COMPONENTS AND HOW THEY WORK IN LEXICAL FUNCTI ONAL GRAMMAR}

Lexicon is the main component in LFG which contains several information in terms of morphological, grammatical, semantics. It is very important to determine the language expressionin lexical grammatical operations. Lexical entries provide information relating to the words and affixes when the information cannot be predicted.

In LFG theory, a word which has meaning such as denotation, referential, or lexical is used to bring predicate features (Pred). In this study, the meaning of the clause will be written with apostrophe " " " after equation sign. Meanwhile, predicate (PRED) of a clause is not always meant as "argumentative predicate" since PRED can also contain no argumentative structure. Another component which does not give lexical meaning without PRED is called determiner because it provides the definition of feature (DEF) with a positive score $(+)$ which means "definite". The up arrow sign like ( 4 Pred) and down arrow sign $(\downarrow D E F)$ are called metavariables. Both arrows arouse to manage the information in $\mathrm{K}$ structure and their correlation with structure-F.

\section{METHOD}

The descriptive qualitative approach is used as the method of the research since it can bring better understanding to follow the plot of the story chronologically. It also helps researchers to find some unexpected results during the research. The benefit of qualitative research is the words will be arranged in the form of story and it is able to give more real, alive, and meaningful impression [9]. The research data are Javanese clauses and Javanese sentences in two series stories 1). 'Watesing Kasabaran' written by Tiwiek SA, published by Jaya Baya in 2010, and 2). 'Ting' written by Dyah Kushar, published by Panyebar Semangat in 2010. 


\section{RESULT AND DISCUSSION}

\section{A. Basic clause with verbal predicate of Javanese language}

Based on semantics-syntax theory, Javanese verb can be classified into three, namely: 1) intransitive verb, 2) monotransitive verb, and 3) double-transitive verb. Meanwhile, regarding the verbal classification, verb can also be classified into three, they are 1) intransitive clause, 2) mono-transitive clause, and 3) double-transitive clause. Those three clauses are discussed more detail as follows.

The intransitive clause is existed as part of semantics properties. Intransitive verb as a predicate in one intransitive clause has a meaning as experiencing verb. In addition, the role of its argumentative semantic is called "experiencer". While action verb is a verb which means as "action" and the role of its argumentative semantic is called "actor or agent". The argument in intransitive verb is placed as the grammatical function or subject [5], [10], [11]. Here are the examples of intransitive clauses:

(1) Wong takon saka jero omah "Someone asks from inside of the house".

(2) Dheweke metu menyang kalangan "He gets out to arena"

The predicate in (1) is takon or asks, and the predicate in (2) is metu or gets out. Both predicates are placed after argument of the clause.

Mono-transitive clause is a clause consisted of two arguments and one predicate. Those two arguments are called as actor (A), agent (ag), undergoer (U) or pasient (Ps) (Folley dan Van Valin, 1984). Here are the examples of mono-transitive clauses:

(3) Sugeng maca tulisan "Sugeng reads the note".

(4) Witono milih rejeki lancar "Witono chooses to have easy income".

The transitive predicates in (3) are maca "read" and in (4) milih "choose". Those two transitive predicates above have two core arguments such as in (3) Sugeng "Sugeng" as agent (read) and tulisan "note" as Ps, and in (4) Witono "Witono" as agent, and rejeki lancar "good fortune" as Ps.

Double-transitive clause is a transitive clause consisted of three core arguments namely agent, benefactive, and theme. They form S-V-O-O pattern. Javanese double-transitive clause can be constructed because there is $N$-l-ake component attached in a mono-transitive clause. The nomina "jago" candidate, as written in dwekejago "he is a candidate" is a nominal with one valency. After $N$-/-ake attached in Nomina, "jago" then changes into njagokake "make someone a candidate". Therefore, the valency transforms from one core argument into three core argument. Here are the examples:

(5) Gemi kok malah njagokake Boma bakal unggul jurite. "Gemi takes Boma a candidate of the winner".
(6) Srining njupukake adhine buku. "Srining takes book for her brother

Based on the investigation of the data above, doubletransitive predicate in (5) is njagokake "make someone a candidate", and (6) is njupukake "take" has three core arguments. They are Gemi "Gemi" as (agent) dan Srining. While, the benefactive of those two clauses are: Boma "Boma" dan adhine "his brother". The theme of those two clauses are: bakal unggul jurite "increasing level". Thus, benefactive position is closer to verb than theme.

\section{B. Basic Clause with Non-verbal Predicates}

Non-verbal predicates in Javanese consisted of nominal or nominal phrase, adjectival or adjectival phrase, preposition or prepositional, and numeralia or numeralia phrase. In the data, nominal predicates clause and adjectival predicates clause are found, meanwhile preposition and numeralia are not found. Because Javanese non-verbal predicates do not have the structure of argument, all nonverbal predicates do not need the presence of argument.

Nominal predicate is a predicate which its substance is a noun. Clause which its predicate filled by noun category is nominal clause, or called equational clause or identification clause [11]. Here are the example of Javanese nominal clause:

(7) Dhewekeki jane asli Jawa "She is an actually native Javanese".

(8) Duwene kari sepedha onthel "Her/his belonging remains only a bicycle".

Based on the examples (7-8) above, each clause consists of an argument $\mathrm{S}$ ( $\mathrm{S}$ is intransitive Subject) and nominal predicate. Predicates on those clauses attribute the right position of S. predicate "native Javanese" in (7) is at the right position or after S dheweke "she/he"; predicate sepedha onthel "bicycle" in (8) is at the right position S duweke "her/his belonging".

Adjectival predicate is a predicate which its substance is an adjective. Clause which its predicate filled by an adjective is adjectival clause, or called adjective clause [4]. The following are Javanese adjective clause:

(9) Omahe mbah Jamila jegregeng "Jamil grandfather's house is always crowded".

(10) Omahku sumpek "my house is narrow".

(11) Srining bungah "Srining is happy".

Each predicate of the clauses above is at the right position of subject. Predicate ajegregeng "is always crowded" in (9) is at the right position of subject omahe mbah Jamil "Jamil Grandfather's house"; predicate sumpek "is narrow" in (10) is at the right position of subject omahku "my house"; predicate bungah "is happy" in (11) is at the right position of subject Srining "someone name". 


\section{CONCLUSION}

Based on the results and discussion, some conclusions can be stated as follows. First, the basic structure of Javanese language clauses consists of grammatical categories, the structure of the clause, and the sequence of the constituent clause, valency, and transitive. Based on grammatical categories, the function of Javanese predicate consists of verbal predicate clauses and non-verbal predicate clauses. The verbal predicate clause consists of intransitive clause, mono-transitive clause and double-transitive clause, in which the predicate clauses do not consist of a verb nominal clause and adjective. The sequence of constituent clause of Javanese language is tight, meaning that the verb as an essential element of clause and to fill specific roles and functions of the clause and appears at certain position; at the beginning, middle, and end of the clause. For example, the subject always comes before the verb or its position is at the left of the verb, while object is put after the verb or at right position, and Javanese language is classified in to Subject Verb Object (SVO) or Subj-Pred-Obj. The verb predicateclause is closely related to the valency of verbs in the Javanese language, the verb with one valent (intransitive clause), double-valent (mono transitive clause), and with three valents (double transitive clause).

\section{REFERENCES}

[1] L. Bauer, The Linguistics Student's Handbook. Edinburg University Press, 2007

[2] J. Bresnan, "Lexical-Functional Syntax Part III: Inflectional Morphology and Phrase Structure Variation," 1998.

[3] M. Dalrymple, R. M. Kaplan, J. T. Maxwell-III, and Z. Annie, Formal Issues in Lexical Functional Grammar. California: CSLI, 1995.

[4] I. W. Arka, "Beberapa Aspek Intransitif Terpilah pada Bahasa-bahasa Nusantara: Sebuah Analisis Leksikal-Fungsional," in Kajian Serba Linguistik, B. K. Purwo, Ed. Jakarta: PT Gunung Mulia, 2000, pp. 423-510.

[5] I. W. Arka, "Tatabahasa Leksikal Fungsional: Tipologinya dan Tantangannya bagi Bahasa-bahasa Nusantara," in PELLBA 16, B. Kaswanti Purwo, Ed. Jakarta: Pusat Kajian Bahasa dan Budaya, Unika Atmajaya, 2003, pp. 51-105.

[6] R. M. Kaplan and J. Bresnan, "Lexical-Functional Grammar: A Formal System for Grammatical Representation," in Formal Issues in Lexical-Functional Grammar, M. Dalrymple, R. M. Kaplan, M. I. Joan T, and A. Z. (Ed), Eds. Stanford, California: CSLI, 1995, pp. 29-30.

[7] P. Sells, Lectures on Contemporary Syntactic Theories. Stanford, California: CSLI, 1985.

[8] M. T. Wescoat and A. Zaenen, "Lexical Functional Grammar," in Linguistic Theory and Grammatical Description, F. G. Droste and J. J.E., Eds. Amsterdam: John Benjamins Publishing, 1991, pp. 103135 .

[9] M. B. Miles and M. Huberman, Analisis Data Kualitatif. Jakarta: Universitas Indonesia (UI-Press), 1992.

[10] R. M. W. Dixon, W. A. Foley, and R. D. Van Valin, Fungsional Syntax and Universal Grammar. Cambridge: Cambridge University Press, 1984.

[11] J. W. M. Verhaar, Asas-Asas Linguitik Umum. Yogyakarta: Gadjah Mada University Press, 1999. 